ARAŞTIRMA / RESEARCH

\title{
Lomber subkutan yağ doku kalınlığının spinopelvik parametrelerle ilişkisi
}

Relationship between lumbar subcutaneous adipose tissue thickness and spinopelvic parameters

Sevil Okan' (D), Murat Beyhan'

${ }^{1}$ Tokat State Hospital. Physical Medicine and Rehabilitation Tokat, Turkey.

${ }^{2}$ Tokat Gaziosmanpaşa Universiy Faculty of Medicine, Department of Radiology, Tokat, Turkey.

\begin{abstract}
Purpose: The aim of this study was too reveal the relationship between lumbar subcutaneous adipose tissue thickness and spinopelvic parameters.

Materials and Methods: This retrospective study included a total of 92 individuals who had lumbosacral radiographs and lumbar magnetic resonance imaging among the people who applied to Tokat State Hospital in October-December 2019 period. Lumbar subcutaneous adipose tissue thickness, pelvic incidence, pelvic tilt, sacral slope, lumbar lordosis and spinopelvic mismatch (Pelvic incidence minus lumbar lordosis) were determined, and correlations between these measurements were evaluated. Results: Subcutaneous adipose tissue thickness was $20.50 \pm 12.34 \mathrm{~mm}$ at $\mathrm{L} 1$ vertebra level and $29.79 \pm 15.68 \mathrm{~mm}$ at $L 5$ vertebra level. Subcutaneous adipose tissue thickness at L1 vertebra level was strongly correlated with body mass index and adipose tissue thickness at L5 vertebra level, but weakly correlated with pelvic tilt and spinal misalignments. Conclusion: Subcutaneous adipose tissue thickness and body mass index increase was positively correlated. In addition, lumbar subcutaneous adipose tissue thickness and body mass index increase have effects on pelvis and spinal alignment. Lumbar subcutaneous adipose tissue thickness could be used to evaluate the effect of body composition on spinopelvic parameters.
\end{abstract}

Keywords:. Body mass index, lumbar subcutaneous adipose tissue thickness, spinopelvic parameter

\section{INTRODUCTION}

Balanced body composition is an important determinant of health and physical performance.

\section{Öz}

Amaç: Lomber subkutan yağ doku kalınlığı ile spinopelvik parametreler arasındaki ilişkiyi değerlendirmektir.

Gereç ve Yöntem: Retrospektif tipte planlanan çalışmaya Ekim 2019 ve Aralık 2019 tarihleri arasında Tokat Devlet Hastanesi'ne başvuran Lomber $\mathrm{MR}$ ve 2-yönlü lumbosakral grafileri çekilmiş olan 92 birey dahil edildi. Lomber subkutan yağ doku kalınlığı, pelvik insidans, pelvik tilt, sakral slop, lomber lordoz ve spinopelvik uyumsuzluk (pelvik insidans minus lomber lordoz) değerleri ölçüldü ve ölçümler arasındaki korelasyon değerlendirildi.

Bulgular: L1 vertebra düzeyinde subkutan yağ doku kalınlığ $20.50 \pm 12.34 \mathrm{~mm}$ tespit edilirken L5 vertebra

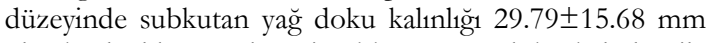
olarak ölçüldü. L1 düzeyi subkutan yağ doku kalınlı̆̆ ile VKI ve L5 vertebra düzeyi subkutan yağ doku kalınlığ1 arasında kuvvetli korelasyon, pelvik tilt ve spinal dizilim bozukluğu arasında zayıf korelasyon tespit edildi $(\mathrm{p}<0.05)$. Sonuç: Subkutan yağ doku kalınlığı ve VKİ deki artış arasında pozitif korelasyon mevcuttu. Buna ek olarak lomber subkuan yağ doku kalınlığı ve VKI' deki artışın pelvik tilt ve spinal dizilim bozukluğu üzerinde etkili olduğu tespit edildi. Lomber subkutan yağ doku kalınlığ1; vücut kompozisyonunun spinopelvik parametreler üzerine etkisinin değerlendirilmesinde kullanılabilir.

Anahtar kelimeler: Vücut kitle indeksi, lomber subkutan yağ doku kalınlığı, spinopelvik parametre

Chronic diseases associated with inactivity and body composition disorders are among the most important public health problems of the $21^{\text {st }}$ century ${ }^{1}$. It was reported that increased body weight may have

Yazışma Adresi/Address for Correspondence: Dr. Sevil Okan, Tokat State Hospital. Physical Medicine and Rehabilitation Tokat, Turkey. doctorsevil@yahoo.com.

Geliş tarihi/Received: 13.05.2020 Kabul tarihi/Accepted: 15.08.2020 Çevrimiçi yayın/Published online: 31.08.2020 
biomechanical effects on pelvis and lumbar spine alignment ${ }^{2}$. Biomechanical changes, in turn, are known to play important roles in the onset and progression of several vertebral pathologies ${ }^{3,4}$. An examination of the differences in the biomechanics of the spine of obese individuals revealed a link between low back pain and body mass index (BMI) ${ }^{5}$. A study evaluating the relationship of lumbar adipose tissue thickness with BMI in 250 individuals showed that the increase in the thickness of the lumbar adipose tissue was associated with the increases in BMI ${ }^{6}$. Another study by Takatalo et al. ${ }^{7}$ in 155 female and 147 male individuals, on the other hand, found a strong correlation between the body fat percentage and dorsal subcutaneous thickness.

Optimal alignment of bones and joints is very important for the effective function of the musculoskeletal system ${ }^{8}$. In order for the body to achieve an effective upright posture, the spine must be compatible with the pelvis. This compatibility describes the synergistic relationship between pelvic morphology and spinal slopes, and is called spinopelvic alignment ${ }^{9}$. Spinopelvic mismatch which develops secondary to change in lumbar lordosis could lead to spinal sagittal imbalance ${ }^{10}$. In individuals with spinal deformity and with decreased lumbar lordosis, on the other hand, impaired quality of life including physical and social functions and increased pain were observed ${ }^{11}$.

Different studies defined normal values of spinopelvic parameters for different ages, populations and pathological conditions 12,13. However, there was no study examining the relationship between these parameters and lumbar subcutaneous adipose tissue thickness. In this study, an objective analysis of the correlation between lumbar subcutaneous adipose tissue thickness and spinopelvic parameters is presented.

\section{MATERIALS AND METHODS}

This retrospective study included 92 of 113 individuals who applied to Tokat State Hospital, in October 2019-December 2019 period, who were 1865 years of age and had both lumbar magnetic resonance imaging (MRI) and bilateral lumbosacral radiographs taken within the last 30 days. Data used in the study (body mass index, age, gender, lumbar MRI and lumbosacral radiographs) were obtained by the author through screening the hospital information system. Four individuals with advanced level bone and disc degeneration, three individuals with spondylolisthesis and 14 individuals with indications of operation in lumbar or pelvic area were excluded (Figure 1). Lumbosacral radiographs and lumbar MR images of the included individuals were evaluated by an experienced radiologist, and subcutaneous adipose tissue thickness, pelvic tilt (PT), pelvic incidence (PI), sacral slope (SS) and lumbar lordosis (LL) were measured. All study protocols were implemented in accordance with the ethical rules proposed in the Helsinki Declaration. The study was approved by Tokat Gaziosmanpaşa University Clinical Research ethics committee (07.02.2020;20-KAEK-015).

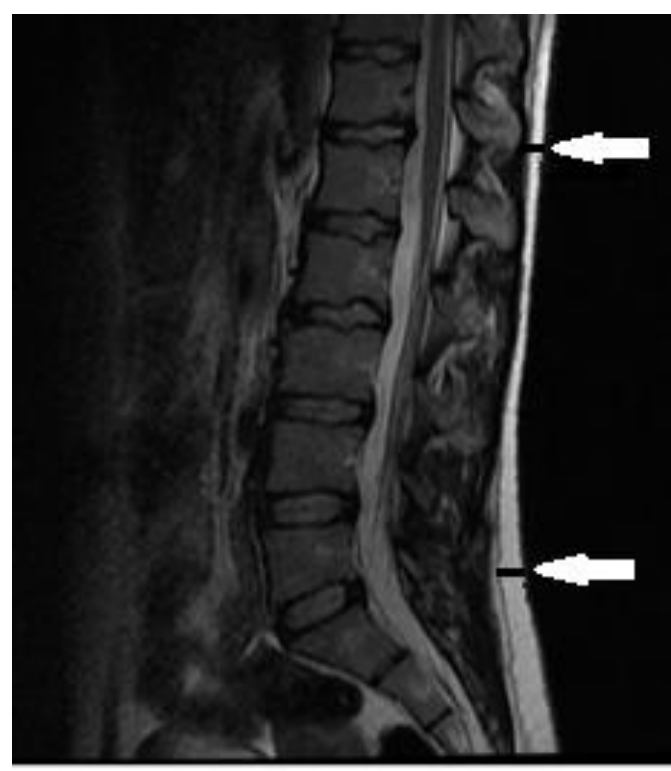

Figure 2. Lumbar subcutaneous adipose tissue measurement

\section{Procedure}

MR Imaging was performed using a 1.5-T MR imaging unit (Optima 360; General Electric Medical Systems, Milwaukee, WI). The dorsal subcutaneous thickness of L1 and L5 levels were evaluated on sagittal T2-weighted fast-recovery fast spin-echo images. The following MR imaging parameters were used: repetition time: 2510; echo time: 81.4 ; slice thickness: $4.0 \mathrm{~mm}$; intersection gap: $1.0 \mathrm{~mm}$; matrix: $256 \times 256$; and field of view: $28 \times 28 \mathrm{~cm}$.

Each patient underwent lateral radiographs of both hip joints in the standing position with their arms folded on their chest and knees fully extended. All 
radiological measurements were performed using the lateral lumbosacral radiographs and lumbar MR images by the radiologist through the picture archiving and communication system.

Lumbar subcutaneous adipose tissue thickness was measured as subcutaneous fat extending to subcutaneous fascia in lumbar MR images as vertical to the skin at the level of L1 vertebra posterior superior corner and L5 vertebra posterior inferior corner 14 (Figure 2).

PI was defined as the angle between the line perpendicular to the sacral plate at its midpoint and the line connecting this point to the axis of femoral heads. SS was measured as the angle between the sacral plate and a horizontal line. PT was defined by the line through midpoint of the sacral plate and midpoint of the axis of femoral heads and the vertical line ${ }^{15}$. LL angle was measured as the angle between the line drawn as parallel to the upper surface of the first vertebra corpus of lumbar and the lines drawn as parallel to the lower surface of the fifth vertebra corpus of lumbar ${ }^{16}$ (Figure 3).

Spinopelvic alignment is typically measured in terms of the mismatch (mathematical difference) between pelvic incidence and lumbar lordosis (PI minus LL or PI-LL). PI-LL $<10^{\circ}$ was considered normal, while $10^{\circ}<$ PI-LL $<20^{\circ}$ was regarded moderate level of deformity, and PI-LL $>20^{\circ}$ serious deformity ${ }^{17}$.

\section{Statistical analysis}

Statistical analyses of the data were performed using SPSS software (Version 22.0, SPSS Inc., Chicago, IL, USA). Continuous variables of descriptive statistics were given as mean \pm standard deviation, while frequency distributions of categorical ones were expressed as number and percentages (\%). Normality of the distributions were evaluated using Kolmogorov-Smirnov test. The differences between group means of quantitative variables were compared using the significance test for the difference between the two means. The Pearson's correlation coefficient was used to determine the relationships between quantitative variables. Correlation was classified as follows: $0.00-0.10$ negligible correlation, $0.10-0.39$ weak correlation, 0.40-0.69 moderate correlation, $0.70-0.89$ strong correlation and $0.90-1.00$ very strong correlation $^{18}$. The $\mathrm{p}$ values lower than 0.05 were considered statistically significant

Individuals who were 18-65 years of age and had both lumbar magnetic resonance imaging (MRI) and bilateral lumbosacral radiographs taken within the last 30 days

(n:113)

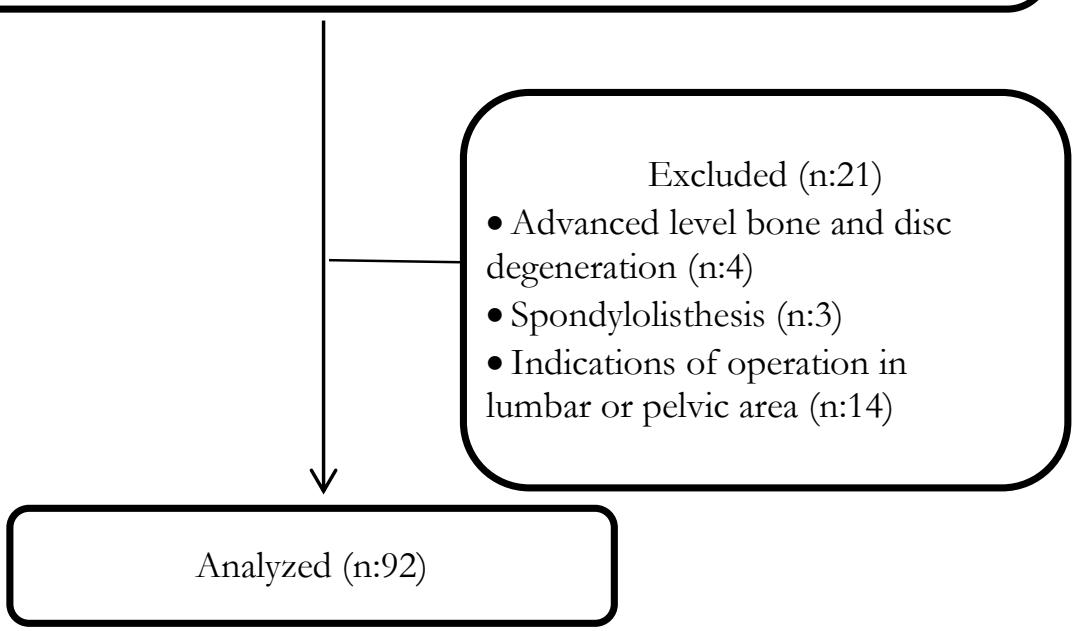

Figure 1. Study Flowchart 


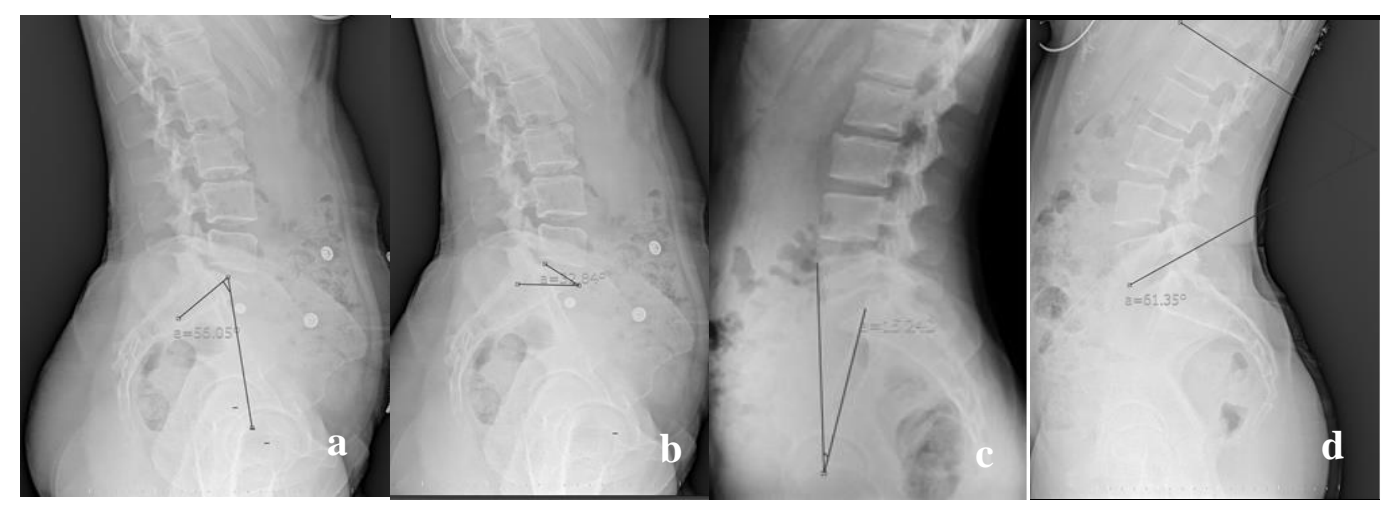

Figure 3. a: Pelvic incidence, b: Sacral slope, c: Pelvic tilt, d: Lumbar lordosis

\section{RESULTS}

Average age of the 92 individuals in the study $(57.6 \%$ women and $42.4 \%$ men) was $46.04 \pm 12.52$ years, and average BMI was $30.59 \pm 5.47$. Subcutaneous adipose tissue thickness was $20.50 \pm 12.34 \mathrm{~mm}$ at L1 vertebra level and $29.79 \pm 15.68 \mathrm{~mm}$ at L5 vertebra level. Spinopelvic parameter averages were LL: $43.05^{\circ} \pm 11.73^{\circ}$; PT: $22.17^{\circ} \pm 7.9^{\circ}$; SS: $36.05^{\circ} \pm 8.38^{\circ}$ and PI: $67.65^{\circ} \pm 9.24^{\circ}$ (Table 1). Although subcutaneous adipose tissue thickness at L1 vertebra level was higher in women, the difference was not significant $(21.93 \pm 12.57 \mathrm{~mm}$ and $18.55 \pm 11.90 \mathrm{~mm}$, respectively, $\mathrm{p}=0.195)$. Subcutaneous adipose tissue thickness at L5 vertebra level (women: 35.98 \pm 15.18 , men: 21.38 $\pm 12.15, \mathrm{p}=0.001$ ) and BMI (women:

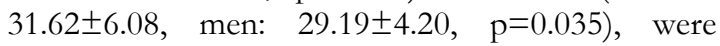
significantly higher in women compared to men.

Subcutaneous adipose tissue thickness at L1 vertebra level was strongly correlated with BMI $(\mathrm{p}=0.001)$ and subcutaneous adipose tissue thickness at L5 vertebra level $(p=0.001)$, while its correlations with PT $(p=0.001)$ and spinal misalignment were weak $(\mathrm{p}=0.027)$.

On the other hand, the correlation between subcutaneous adipose tissue thickness at L5 vertebra level and BMI was moderately strong $(p=0.001)$. Besides, BMI was weakly correlated with PT $(p=0.005)$ and spinal misalignment $(p=0.046)$. There was a strong negative correlation between LL and spinal misalignment $(p=0.001)$ whereas LL had moderately strong correlations with SS $(p=0.001)$ and PI $(p=0.002)$. PI also had moderately strong correlations with SS $(p=0.001)$, PT $(p=0.001)$ and spinal misalignments $(p=0.001)$. The correlation between spinal misalignment and PT, on the other hand, was weak $(\mathrm{p}=0.001)$ (Table 2). Normal spinal alignment was observed in $16.3 \%$ of the individuals, while $14.1 \%$ had moderate level and $69.6 \%$ had serious level of spinal misalignment.

Table 1. Age, BMI and spinopelvic parameter means of all individuals

\begin{tabular}{|l|c|c|}
\hline & Mean & Standard deviation \\
\hline Age $($ year $)$ & 46.04 & 12.52 \\
\hline BMI $\left(\mathrm{kg} / \mathrm{m}^{2}\right)$ & 30.59 & 5.47 \\
\hline L1 LSAT* $(\mathrm{mm})$ & 20.50 & 12.34 \\
\hline L5 LSAT* $(\mathrm{mm})$ & 29.79 & 15.68 \\
\hline Lumbar lordosis $\left(^{\circ}\right)$ & 43.05 & 11.73 \\
\hline Pelvic tilt $\left(^{\circ}\right)$ & 22.17 & 7.97 \\
\hline Sacral slope $\left(^{\circ}\right)$ & 36.05 & 8.38 \\
\hline Pelvic incidence $\left(^{\circ}\right)$ & 67.65 & 9.24 \\
\hline
\end{tabular}

* LSAT: Lumbar subcutaneous adipose tissue 
Table 2. Correlations between lumbar subcutaneous adipose tissue thickness, BMI and spinopelvic parameters

\begin{tabular}{|ll|l|l|l|l|l|l|l|l|l|}
\hline & & & $\mathbf{1}$ & $\mathbf{2}$ & $\mathbf{3}$ & $\mathbf{4}$ & $\mathbf{5}$ & $\mathbf{6}$ & $\mathbf{7}$ & $\mathbf{8}$ \\
\hline 1 & Pelvic incidence & $\mathrm{r}$ & $\mathbf{1}$ & & & & & & & \\
\hline 2 & Sacral slope & $\mathrm{r}$ & $.432^{* *}$ & 1 & & & & & & \\
\hline 3 & Pelvic tilt & $\mathrm{r}$ & $.477^{* *}$ & -.187 & 1 & & & & & \\
\hline 4 & Lumbar lordosis & $\mathrm{r}$ & $.320^{* *}$ & $.473^{* *}$ & -.025 & 1 & & & & \\
\hline 5 & L1 LSAT*** & $\mathrm{r}$ & .117 & -.097 & $.378^{* *}$ & -.151 & 1 & & & \\
\hline 6 & L5 LSAT*** & $\mathrm{r}$ & .016 & -.187 & .127 & -.083 & $.737^{* *}$ & 1 & & \\
\hline 7 & BMI & $\mathrm{r}$ & .139 & -.064 & $.288^{* *}$ & -.111 & $.725^{* *}$ & $.663^{* *}$ & 1 & \\
\hline 8 & PI-LL & $\mathrm{r}$ & $.442^{* *}$ & -.126 & $.380^{* *}$ & $-.708^{* *}$ & $.230^{*}$ & .091 & $.209^{*}$ & 1 \\
\hline
\end{tabular}

Pearson correlation coefficient was used. *. Correlation is significant at the 0.05 level (2-tailed). ${ }^{* *}$. Correlation is significant at the 0.01 level (2-tailed). ***LSAT: Lumbar subcutaneous adipose tissue.

\section{DISCUSSION}

It was suggested that increased body weight could cause mechanical problems due to the load on the back and biomechanical effect ${ }^{2}$. Increased body weight and obesity are currently considered as the major health problems affecting people around the world ${ }^{19}$. The results of the present study showed that BMI increases were associated with the increases in subcutaneous adipose tissue thickness at L1 and L5 vertebra levels. In support of the findings of the present study, a study showed that increased BMI was associated with increased subcutaneous adipose tissue thickness in the lumbar spine ${ }^{6}$. The fact that a considerable part of body fat is accumulated around the waist could explain the relationship between the BMI and lumbar adipose tissue thickness. WallnerLiebmann et al. ${ }^{20}$ on the other hand, evaluated the obesity using subcutaneous adipose tissue measurements without measuring the thickness of the lumbar adipose tissue itself. They used an optical Lipometer device to measure the topography of subcutaneous adipose tissue consisting of 15 welldefined body areas scattered from neck to calf on the right side of the body. They also reported that subcutaneous fat patterns are better screening tools than BMI to characterize the obesity in physically active youth. Based on that study and considering the association between BMI and subcutaneous adipose tissue thickness observed in the present study, it could be proposed that lumbar subcutaneous adipose tissue thickness could be used as an obesity marker instead of BMI. However, large scale studies are needed to support such proposal.

In the present study, subcutaneous adipose tissue thickness was higher in women. In parallel to findings of the present study, Klare et al. ${ }^{6}$ also reported higher average subcutaneous adipose tissue thickness for women. Similarly, another study in which the relationship between the BMI values of 149 individuals and lumbar adipose tissue thickness at both L1 and L5 levels were evaluated, it was found that women's adipose tissue thickness was higher than that of men ${ }^{14}$. This finding could be explained by the fact that in women estrogen receptors are more common and androgen receptors are found less in subcutaneous adipose tissue, while in men androgen receptors are more predominant in visceral adipose tissue ${ }^{21}$. Higher prevalence of estrogen receptors in subcutaneous adipose tissue in women could lead to higher subcutaneous adipose tissue thickness in women due to estrogen compared to men.

Literature analysis shows that increasing body weight could have a biomechanical effect on the spatial orientation of the pelvis and lumbar spine ${ }^{2}$. The present study revealed that increasing BMI and subcutaneous adipose tissue thickness at L1 vertebra level were associated with increased PT and spinal misalignment severity. In another study where the relationship between sagittal spinopelvic parameters and obesity were evaluated in normal adolescents and adolescents with lumbar disc herniation, it was observed that as the BMI increased PI, PT, SS and 
LL also increased in adolescents with lumbar disc herniation ${ }^{22}$. Increasing PT along with increasing BMI could possibly be due to the back slope of the pelvis to balance the body displacement towards the front in an overweight patient population ${ }^{23}$. It is possible that similar to what happens in BMI increase, new arrangements could take place in pelvis and spinal alignment to compensate the increase in adipose tissue thickness and to establish a new balance. In contrast, Zawojska et al. ${ }^{24}$ found that PT parameters were lower in people with higher BMI, but the differences were not significant. The reason for the observation of a different association between PT measurements and BMI in that study could be the fact that the study population was made of hemophilia patients and these patients could have other mechanic factors such as knee joint contracture.

In the present study, as the BMI and subcutaneous adipose tissue thickness increased, PI increased, but SS and LL decreased although the differences were not significant. Similarly, in another study evaluating 200 participants, no significant differences were observed among normal, overweight and obese individuals for sagittal spinopelvic parameters ${ }^{15}$. In a study evaluating the relationship of obesity with the LL angle in premenopausal women, the increase in BMI was found to be associated with a decrease in LL ${ }^{25}$. Contrary to present study, a study reported association of higher BMI values with larger SS 24 . Based on these data, it could be stated that increases in the thickness of lumbar subcutaneous adipose tissue and the BMI could lead to deterioration in the spinal alignment through changing the spinopelvic parameters.

In the present study, LL, SS, PI, PT averages were $43.05 \pm 11.73^{\circ}, \quad 36.05 \pm 8.38^{\circ}, \quad 67.65 \pm 6.24^{\circ}$ and $22.17 \pm 7.97^{\circ}$. Thus, PI, PT and LL values showed differences from the values measured previously in healthy individuals $\left[37^{\circ}\right.$ (range 22-53) for LL; 50.6 (range 39-62) for PI; $12.6^{\circ}$ (range 3-22) for PT] ${ }^{26}$. All components of spinopelvic alignment somehow contribute to the overall alignment ${ }^{27}$. Previous studies showed that sagittal spinopelvic alignment that leads to biomechanical changes was shown to play role in the pathogenesis and development of lumbar degenerative diseases ${ }^{28,29}$. In the present study, spinal misalignment (PI-LL) was found to be associated with subcutaneous adipose tissue thickness at L1 vertebra level, BMI, PI, PT and LL. Similarly, in another study with a cohort of obese patients, LL was found to be reduced and PI-LL misalignment was higher ${ }^{30}$. Contrary to all these, in a study by Park et al. ${ }^{31}$ no difference was reported between the preoperative sagittal alignments, LL and PT angles of obese $(n=18)$ and non-obese $(n=59)$ individuals who underwent minimally invasive surgeries. This difference could be due to the fact that the number of obese individuals in the study was low compared to non-obese individuals. In light of this data, it seems that both changes in spinopelvic parameters and increases in BMI and lumbar subcutaneous adipose tissue thickness lead to impairment in spinal alignment.

The present study is the first to evaluate the relationship of lumbar subcutaneous adipose tissue thickness with spinopelvic parameters. Limitation of the study is that the effect of lumbar adipose tissue thickness on all spine alignment could not be evaluated since the sagittal vertical axis was not measured. In addition, since the present study has a retrospective design, no information could be collected regarding the dietary habits and exercise status of the individuals.

Increases in subcutaneous adipose tissue thickness and BMI could be associated with themselves as well as with PT and spinal misalignment. The results point out that the increased lumbar subcutaneous adipose tissue thickness and BMI could affect spatial orientation of pelvis and spine, and could lead to impairment in lumbopelvic complex. In addition, it was found that lumbar subcutaneous adipose tissue thickness could be used for the evaluation of the effect of body composition on spinal alignment and pelvic tilt.

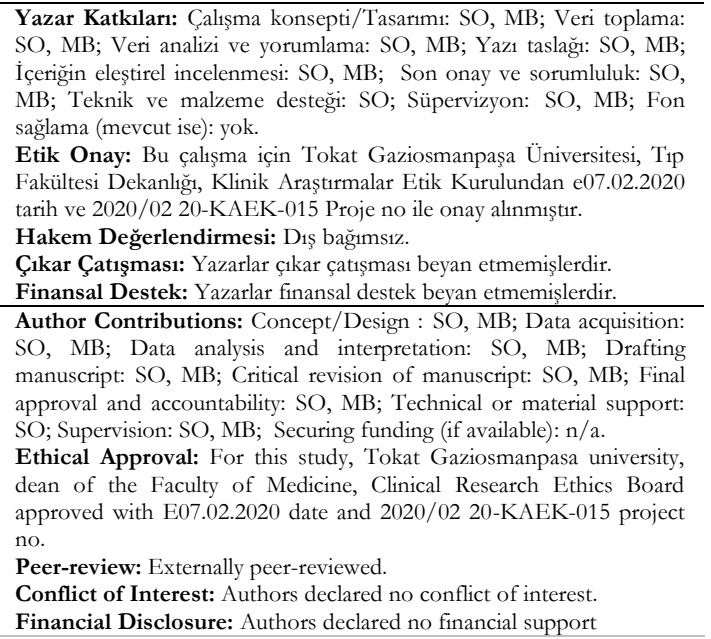




\section{REFERENCES}

1. Blair SN. Physical inactivity: the biggest public health problem of the 21st century. Br J Sports Med. 2009;43:1-2.

2. Onyemaechi NO, Anyanwu GE, Obikili EN, Onwuasoigwe O, Nwankwo OE. Impact of overweight and obesity on the musculoskeletal system using lumbosacral angles. Patient Prefer Adherence. 2016;10:291

3. Funao H, Tsuji T, Hosogane N, Watanabe K, Ishii K, Nakamura $\mathrm{M}$ et al. Comparative study of spinopelvic sagittal alignment between patients with and without degenerative spondylolisthesis. Eur Spine J. 2012;21:2181-7.

4. Barry C, Jund J, Noseda O, Roussouly P. Sagittal balance of the pelvis-spine complex and lumbar degenerative diseases. A comparative study about 85 cases. Eur Spine J. 2007;16:1459-67.

5. Sheng B, Feng C, Zhang D, Spitler H, Shi L. Associations between obesity and spinal diseases: a medical expenditure panel study analysis. Int J Environ Res Public Health. 2017;14:183

6. Klare C, Johnson N, Chapman T, Darden B, Davidson D, Milam A. Comparison of subcutaneous fat thickness in the lumbar spine related to bmi between males and females. J Neurosurg Spine. 2019;30:45.

7. Takatalo J, Karppinen J, Taimela S, Niinimäki J, Laitinen J, Sequeiros RB et al. Association of abdominal obesity with lumbar disc degeneration--a magnetic resonance imaging study. PLoS One. 2013;8:e56244.

8. Schwab F, Patel A, Ungar B, Farcy J, Lafage V. Adult spinal deformity-postoperative standing imbalance: how much can you tolerate? An overview of key parameters in assessing alignment and planning corrective surgery. Spine (Phila $\mathrm{Pa}$ 1976). 2010;35:2224-31.

9. Vaz G, Roussouly P, Berthonnaud E, Dimnet J. Sagittal morphology and equilibrium of pelvis and spine. Eur Spine J. 2002;11:80-7.

10. Diebo BG, Ferrero E, Lafage R, Challier V, Liabaud B, Liu $S$ et al. Recruitment of compensatory mechanisms in sagittal spinal malalignment is age and regional deformity dependent: a full-standing axis analysis of key radiographical parameters. Spine (Phila Pa 1976). 2015;40:642-9.

11. Glassman SD, Bridwell K, Dimar JR, Horton W, Berven S, Schwab F. The impact of positive sagittal balance in adult spinal deformity. Spine (Phila $\mathrm{Pa}$ 1976). 2005;30:2024-9.

12. O'Sullivan PB, Dankaerts W, Burnett AF, Farrell GT, Jefford E, Naylor CS. Effect of different upright sitting postures on spinal-pelvic curvature and trunk muscle activation in a pain-free population. Spine. 2006;31:E707-E712.
13. Vialle R, Levassor N, Rillardon L, Templier A, Skalli W, Guigui P. Radio.graphic analysis of the sagittal alignment and balance of the spine in asymptomatic subjects. J Bone Jt Surg Am. 2005;87:260-7.

14. West W, Brady-West D, West KP. A comparison of statistical associations between oedema in the lumbar fat on MRI, BMI and back fat thickness (BFT). Heliyon. 2018;4(1):e00500.

15. Romero-Vargas S, Zárate-Kalfópulos B, OteroCámara E, Rosales-Olivarez L, Alpízar-Aguirre A, Morales-Hernández E, et al. The impact of body mass index and central obesity on the spino-pelvic parameters: a correlation study. Eur Spine J. 2013;22:878-82.

16. Berthonnaud E, Labelle H, Roussouly P, Grimard G, Vaz G, Dimnet,J. A variability study of computerized sagittal spinopelvic radiologic measurements of trunk balance. Clin Spine Surg. 2005;18:66-71.

17. Schwab FJ, Bess S, Blondel B, Hostin R, Shaffrey C, Smith JS et al. combined assessment of pelvic tilt, pelvic incidence/lumbar lordosis mismatch and sagittal vertical axis predicts disability in adult spinal deformity: a prospective analysis. Spine J Meeting Abstracts. 2011:65.

18. Schober P, Boer C, Schwarte LA. Correlation coefficients: appropriate use and interpretation. Anesthesia Analgesia. 2018;126:17638.

19. Haslam D, James W. Obesity. Lancet. 2005;366:11971209.

20. Wallner-Liebmann SJ, Kruschitz R, Hübler K, Hamlin MJ, Schnedl WJ, Moser M et al. A measure of obesity: BMI versus subcutaneous fat patterns in young athletes and nonathletes. Coll Antropol. 2013;37:3517.

21. Chang E, Varghese M, Singer K. Gender and sex differences in adipose tissue. Current diabetes reports. 2018;18:69.

22. Wang T, Wang H, Liu F, Yang D, Ma L, Ding W. The characteristics of spino-pelvic sagittal parameters and obesity factors for adolescents with lumbar disc herniation. Int J Clin Exp Med. 2016;9:14321-8.

23. Schuller S, Charles YP, Steib JP. Sagittal spinopelvic alignment and body mass index in patients with degenerative spondylolisthesis. Eur Spine J. 2011;20:713-9.

24. Zawojska K, Wnuk-Scardaccione A, Bilski J, Nitecka E. Correlation of body mass index with pelvis and lumbar spine alignment in sagittal plane in hemophilia patients. Medicina. 2019;55:627.

25. Song MY, Chung WS, Kim SS, Shin HD. Correlation between obesity and lumbar lordosis in obese premenupausal Korean females. J Korean Orient Med. 2004;25:43-50.

26. Noshchenko A, Hoffecker L, Cain CM, Patel VV, Burger EL. Spinopelvic parameters in asymptomatic subjects without spine disease and deformity. Clin Spine Surg. 2017;30:392-403. 
27. Kim PK. Case Presentation of Sagittal Balance. Spine (Phila Pa 1976). 2016;41:S20.

28. Aono K, Kobayashi T, Jimbo S, Atsuta Y, Matsuno T. Radiographic analysis of newly developed degenerative spondylolisthesis in a mean twelve-year prospective study. Spine (Phila Pa 1976). 2010;35:88791.

29. Roussouly P, Gollogly S, Berthonnaud E, Dimnet J. Classification of the normal variation in the sagittal alignment of the human lumbar spine and pelvis in the standing position. Spine (Phila Pa 1976). 2005;30:34653
30. Horn SR, Bortz CA, Ramachandran S, Poorman GW, Segreto F, Siow M. Suboptimal age-adjusted lumbopelvic mismatch predicts negative cervical-thoracic compensation in obese patients. Int J Spine Surg. 2019;13:252-61.

31. Park P, Wang MY, Nguyen S, Mundis GM Jr, La Marca F, Uribe JS et al. Comparison of complications and clinical and radiographic outcomes between nonobese and obese patients with adult spinal deformity undergoing minimally invasive surgery. World Neurosurg. 2016;87:55-60 